\title{
Age-related cardiovascular response to tilt test in healthy volunteers of
}

\section{both sexes}

\author{
Sadia Afrin Rimi, Sultana Ferdousi and Shamima Sultana
}

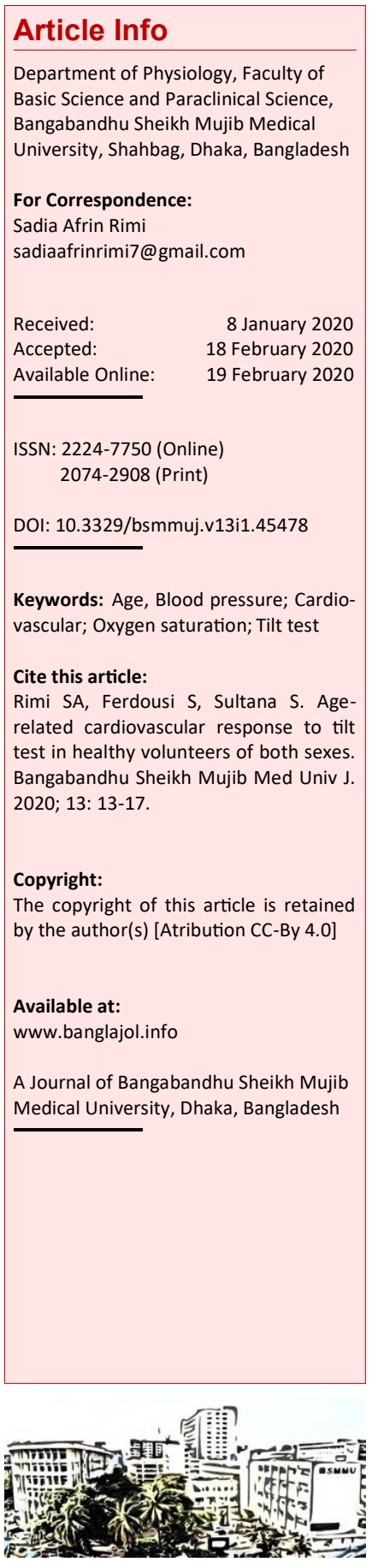

\section{Abstract}

This study aimed to assess the age-related changes in the cardiovascular response to tilt test in 90 healthy individuals of both sexes (age range: 18-60 years). Tilting was done at $60^{\circ}$ for 10 min using a motorized tilt table. The blood pressure was recorded by a sphygmomanometer. The heart rate and peripheral capillary oxygen saturation were measured by a pulse oximeter. In males, significantly lesser changes in the systolic, diastolic and mean arterial pressure were observed in the old age (47-60 years) than the young (18-32 years) and middle age (33-46 years) groups. Significantly lesser responses in the heart rate and systolic blood pressure change were observed in the old age females compared to young age after tilting. The rise of diastolic blood pressure after tilting was lesser in the old age female compared to both young and middle-age females. In conclusion, the aging process is associated with attenuated cardiovascular response to tilt test in both males and females.

\section{Introduction}

Transient loss of consciousness due to cerebral hypoperfusion is known as syncope.1-2 Sudden fall due to syncope sometimes results in the fractures of extremities, hips, skull and face. Syncope while driving can be extremely dangerous even fatal. 3 The failure of the cardiovascular reflex response is one of the major causes of syncope. Orthostatic intolerance is the major contributing factor to the syncope. 4 The postural hypotension is the second most common etiology of syncope $(15 \%)$. It is the wellrecognized feature of cardiovascular autonomic dysfunction. 5 The postural hypotension has defined as a reduction of systolic blood pressure of at least $20 \mathrm{~mm} \mathrm{Hg}$ or more or a reduction of diastolic blood pressure of at least $10 \mathrm{~mm} \mathrm{Hg}$, within $3 \mathrm{~min}$ of standing or head-up tilt to at least $60^{\circ}$ on a tilt table. $-5-7$ The prevalence is $5 \%$ in subjects below 50 years of age and $30 \%$ in subjects greater than 70 years of age. $\frac{5}{}$ In addition to the advanced age, hypertension, diabetes mellitus, bed rest, low body mass index and several medications might have been linked to postural hypotension.

The cardiovascular response can be assessed by measuring heart rate and blood pressure. In case of laboratory and bedside evaluation of patients with suspected autonomic failure, the measurement of changes in the blood pressure and heart rate induced by active standing or passive tilting are necessary. $\frac{9}{-}$

To demonstrate susceptibility to syncope, headup tilt testing is the gold standard clinical test. The response to tilt test may vary physiologically with the age and sex in the healthy subjects. Research evidence showed a strong relationship between aging and change in arterial physiology. Previous studies investigated the tilt test in different age groups to observe the age-related change in heart rate and blood pressure variation in response to tilt.10-13 There were a few published data on cardiovascular response to tilt investigated difference between the male and female, but they did not analyze the data based on age. $.4,15$ Therefore, this present study had been designed to observe the cardiovascular response to tilt in male $\tau$ and female $ఢ$ separately on different ages.

\section{Materials and Methods}

This experimental study was carried out from March 2019 to December 2019. A total number of 90 healthy subjects 18-60 years of age, of both gender were enrolled by purposive sampling. The subjects were selected from relatives and attendants of the patients, hospital staff and also through personal contacts.

Thirty healthy subjects of 18-32 years were in the young age group, 30 subjects of 33-46 years were in the middle age group and 30 subjects of 
47-60 years were in the old age group. All the groups were further subdivided into males and females.

The aim and procedure of this study were explained before taking informed written consent from the participants. Then a detailed personal, medical, family, socio-economic, occupational, dietary history and in case of female menstrual history were taken. A thorough physical examination of the subject was done and documented. Anthropometric measurements including height and weight were taken and body mass index was calculated. All information were documented in a prefixed data schedule. Then $8 \mathrm{~mL}$ of venous blood was collected under aseptic precautions for the biochemical tests (hemoglobin, thyroid stimulating hormone, serum alanine transaminase, serum creatinine, fasting blood sugar levels) and ECG (MAC 4003 channel ECG machine, General Electric Company, India) was also done. All the subjects were free from diabetes, thyroid disorder, anemia, liver disease, renal and cardiovascular disease.

Before doing the head-up tilt test, the subject was instructed to fast for 1 hour. They were requested not to drink or smoke during that time. Just before the examination, the subject was asked to urinate. Then the subject was asked to lie down on a tilt table and given $10 \mathrm{~min}$ for rest. Then supine heart rate, peripheral capillary oxygen saturation and systolic blood pressure, diastolic blood pressure, mean arterial pressure were recorded. Then tilting was done at $60^{\circ}$ for $10 \mathrm{~min}$ by a motorized tilt table with Hi-Lo Mode (220 volt) Cat No: IEMR4093HL (International Elecro Medical Co, India) with a remote control. Data were recorded for every min for $10 \mathrm{~min}$ after tilting. After $10 \mathrm{~min}$, the tilt table was brought back to the horizontal position. The maximum change in the heart rate and blood pressure after tilting was considered as the cardiovascular response to tilt. During the tilt, the subject was asked to avoid the movement of the lower limb. The subject was also instructed if he/ she felt any dizziness, lightheadedness or discomfort he/she must inform it to the operator so that the tilting would be ceased immediately and the table would be brought back to the horizontal position. The blood pressure was recorded by an automatic sphygmomanometer (HME-7120, Omron Health Care Co. Ltd., Vietnam). The heart rate and $\mathrm{SpO}_{2}$ were measured by the pulse oximeter (YK-88 LED, Yonker, China). $\underline{12,13}$

\section{Statistical analysis}

Data were expressed as mean \pm SD. Statistical analysis was done using SPSS version 22 . One-way ANOVA followed by Bonferroni was done. $p$ value of $\leq 0.05$ was considered as statistically significant.

\section{Results}

All parameters of blood pressure were significantly higher in the old age females compared to both young age and middle-age females. But there was no age-related significant difference in all the parameters in males (Table I).

In males, significantly lesser change in systolic blood pressure, diastolic blood pressure and mean arterial pressure was noted in old age than young age only (Table II).

\begin{tabular}{|c|c|c|c|c|c|c|}
\hline \multicolumn{7}{|c|}{ Table I } \\
\hline \multicolumn{7}{|c|}{ General characteristics of subjects } \\
\hline \multirow[t]{2}{*}{ Groups } & \multicolumn{2}{|c|}{$\begin{array}{c}\text { Young age } \\
(n=30)\end{array}$} & \multicolumn{2}{|c|}{$\begin{array}{l}\text { Middle age } \\
(n=30)\end{array}$} & \multicolumn{2}{|c|}{$\begin{array}{l}\text { Old age } \\
(n=30)\end{array}$} \\
\hline & Male & Female & Male & Female & Male & Female \\
\hline Age (years) & $\begin{array}{l}28.8 \\
(2.6)\end{array}$ & $\begin{array}{l}28.1 \\
(3.2)\end{array}$ & $\begin{array}{l}36.7 \\
(3.1)\end{array}$ & $\begin{array}{l}35.6 \\
(2.5)\end{array}$ & $\begin{array}{l}54.7 \\
(4.5)\end{array}$ & $\begin{array}{r}51.7 \\
(4.8 \mathrm{a})\end{array}$ \\
\hline Heart rate (beats/min) & $\begin{array}{r}79.3 \\
(10.0)\end{array}$ & $\begin{array}{r}74.1 \\
(10.1)\end{array}$ & $\begin{array}{l}73.1 \\
(8.2)\end{array}$ & $\begin{array}{l}76.3 \\
(8.3)\end{array}$ & $\begin{array}{l}76.9 \\
(7.7)\end{array}$ & $\begin{array}{r}77.2 \\
(11.4)\end{array}$ \\
\hline $\begin{array}{l}\text { Peripheral capillary oxygen saturation } \\
\left(\mathrm{SpO}_{2}\right)(\%)\end{array}$ & $\begin{array}{l}96.1 \\
(2.5)\end{array}$ & $\begin{array}{l}96.7 \\
(2.6)\end{array}$ & $\begin{array}{r}96.3 \\
(1.9)\end{array}$ & $\begin{array}{l}97.0 \\
(2.4)\end{array}$ & $\begin{array}{r}93.1 \\
(4.6)\end{array}$ & $\begin{array}{r}96.2 \\
(3.3)\end{array}$ \\
\hline Systolic blood pressure (mm Hg) & $\begin{array}{r}121.3 \\
(6.5)\end{array}$ & $\begin{array}{r}102.2 \\
(9.1)\end{array}$ & $\begin{array}{r}118.9 \\
(7.0)\end{array}$ & $\begin{array}{l}107.2 \\
(10.4)\end{array}$ & $\begin{array}{l}124.1 \\
(14.1)\end{array}$ & $\begin{array}{r}119.8 \\
\left(13.4^{\mathrm{ab}}\right)\end{array}$ \\
\hline Diastolic blood pressure $(\mathrm{mm} \mathrm{Hg})$ & $\begin{array}{l}76.6 \\
(6.5)\end{array}$ & $\begin{array}{l}65.1 \\
(7.4)\end{array}$ & $\begin{array}{l}76.9 \\
(8.8)\end{array}$ & $\begin{array}{l}69.6 \\
(8.0)\end{array}$ & $\begin{array}{l}79.3 \\
(8.4)\end{array}$ & $\begin{array}{r}77.0 \\
\left(9.0^{\mathrm{ab}}\right)\end{array}$ \\
\hline Mean blood pressure (mm Hg) & $\begin{array}{l}91.4 \\
(5.2)\end{array}$ & $\begin{array}{l}77.9 \\
(8.4)\end{array}$ & $\begin{array}{l}90.2 \\
(2.0)\end{array}$ & $\begin{array}{l}82.1 \\
(8.6)\end{array}$ & $\begin{array}{l}94.2 \\
(9.9)\end{array}$ & $\begin{array}{r}91.1 \\
(9.9 a b)\end{array}$ \\
\hline
\end{tabular}




\begin{tabular}{|c|c|c|c|}
\hline \multicolumn{4}{|c|}{ Table II } \\
\hline \multicolumn{4}{|c|}{$\begin{array}{c}\text { Rise of } \mathrm{HR}, \mathrm{DBP}, \mathrm{MAP} \text { and fall of } \mathrm{SpO}_{2}, \mathrm{SBP} \text { in males and } \\
\text { females of different age groups after tilting }\end{array}$} \\
\hline Parameters & $\begin{array}{l}\text { Young age } \\
\quad(n=15)\end{array}$ & $\begin{array}{l}\text { Middle age } \\
(\mathrm{n}=15)\end{array}$ & $\begin{array}{c}\text { Old age } \\
(n=15)\end{array}$ \\
\hline \multicolumn{4}{|l|}{ Male } \\
\hline $\begin{array}{l}\text { Rise of heart rate (beats/ } \\
\text { min) }\end{array}$ & $\begin{array}{l}12.7 \\
(6.7)\end{array}$ & $\begin{array}{r}9.8 \\
(5.6)\end{array}$ & $\begin{array}{r}7.5 \\
(6.6)\end{array}$ \\
\hline Fall of $\mathrm{SpO}_{2}(\%)$ & $\begin{array}{r}6.1 \\
(4.4)\end{array}$ & $\begin{array}{r}4.6 \\
(4.6)\end{array}$ & $\begin{array}{r}4.7 \\
(4.0)\end{array}$ \\
\hline $\begin{array}{l}\text { Fall of systolic blood } \\
\text { pressure }(\mathrm{mm} \mathrm{Hg})\end{array}$ & $\begin{array}{r}4.9 \\
(1.5)\end{array}$ & $\begin{array}{r}6.8 \\
(4.8)\end{array}$ & $\begin{array}{r}8.7 \\
\left(4.6^{\mathrm{a}}\right)\end{array}$ \\
\hline $\begin{array}{l}\text { Rise of diastolic blood } \\
\text { pressure }(\mathrm{mm} \mathrm{Hg})\end{array}$ & $\begin{array}{r}9.9 \\
(4.4)\end{array}$ & $\begin{array}{r}8.9 \\
(3.9)\end{array}$ & $\begin{array}{r}6.3 \\
(3.6 \mathrm{a})\end{array}$ \\
\hline $\begin{array}{l}\text { Rise of mean arterial } \\
\text { pressure }(\mathrm{mm} \mathrm{Hg})\end{array}$ & $\begin{array}{r}6.2 \\
(4.0)\end{array}$ & $\begin{array}{r}7.6 \\
(3.6)\end{array}$ & $\begin{array}{r}3.6 \\
(2.7 \mathrm{a})\end{array}$ \\
\hline \multicolumn{4}{|l|}{ Female } \\
\hline $\begin{array}{l}\text { Rise of heart rate (beats/ } \\
\text { min) }\end{array}$ & $\begin{array}{l}12.9 \\
(5.1)\end{array}$ & $\begin{array}{r}9.9 \\
(4.5)\end{array}$ & $\begin{array}{r}8.8 \\
(9.9 \mathrm{a})\end{array}$ \\
\hline Fall of $\mathrm{SpO}_{2}(\%)$ & $\begin{array}{r}3.2 \\
(3.5)\end{array}$ & $\begin{array}{r}6.1 \\
(3.9)\end{array}$ & $\begin{array}{r}5.8 \\
(4.3)\end{array}$ \\
\hline $\begin{array}{l}\text { Fall of systolic blood } \\
\text { pressure }(\mathrm{mm} \mathrm{Hg})\end{array}$ & $\begin{array}{r}6.9 \\
(3.2)\end{array}$ & $\begin{array}{r}9.8 \\
(4.9)\end{array}$ & $\begin{array}{r}11.5 \\
(6.6 \mathrm{a})\end{array}$ \\
\hline $\begin{array}{l}\text { Rise of diastolic blood } \\
\text { pressure }(\mathrm{mm} \mathrm{Hg})\end{array}$ & $\begin{array}{r}8.9 \\
(3.3)\end{array}$ & $\begin{array}{r}7.5 \\
(6.5)\end{array}$ & $\begin{array}{r}4.7 \\
\left(2.5^{\mathrm{ab}}\right)\end{array}$ \\
\hline $\begin{array}{l}\text { Rise of mean arterial } \\
\text { pressure }(\mathrm{mm} \mathrm{Hg})\end{array}$ & $\begin{array}{r}6.7 \\
(3.4)\end{array}$ & $\begin{array}{r}4.0 \\
(2.3)\end{array}$ & $\begin{array}{r}5.1 \\
(3.8)\end{array}$ \\
\hline
\end{tabular}

Again, after tilting significantly lesser response in heart rate and systolic blood pressure change was observed in old age female compared to young age only. In addition, the rise of diastolic blood pressure after tilting was lesser in old age females compared to both young and middle-age females (Table II).

\section{Discussion}

A significant greater fall of systolic blood pressure and a lesser rise of diastolic blood pressure were noted in the older age group of both males and females compared to their younger age group. A significant smaller rise of mean arterial pressure was noted in older males whereas no similar change in mean arterial pressure was found in females.

Lesser rise of heart rate after tilting in older female subjects, but not in male subjects of older age was observed in this study.

Estimation of $\mathrm{SpO}_{2}$ was done in different age groups to observe the response of tissue perfusion in response to orthostatic stress. Our data showed no significant change in tissue perfusion in different age groups after tilting, indicating that age might not have any significant influence on tissue blood flow in both female and male in response to posture.

The change of systolic blood pressure and diastolic blood pressure is similar to the report of Dambrink and Wieling (1987), who also found a similar greater fall of systolic blood pressure and a smaller rise of diastolic blood pressure in older age groups.10 But in contrast, Hansiworth and AlShamma (1988) reported no significant change in systolic blood pressure, but a similar change in diastolic blood pressure after tilting in older age group. $\underline{12}$ No report on the mean arterial pressure change was available.

The findings of heart rate change after tilting in this study suggests an aging effect on cardiac response is more pronounced in female. Similar previous studies show similar age effect on smaller heart rate rise irrespective of gender. $\underline{12}$

In coherence with previous studies, age effect on limitation of circulatory adjustment to postural challenge is supported by the data of present study which further demonstrated similar pattern of aging effect on orthostatic cardiovascular response in both gender.10,12 One study analyzed the tissue perfusion by estimating oxygen saturation in muscle and brain to find out the contribution of hemodynamics to the pathophysiology of syncope.16 They suggested that abrupt increase in muscle blood flow during tilting predicts the fall of oxygen saturation in cerebral blood flow which signals imminent syncope. $\underline{17}$

During head-up tilt as a result of a sudden change of posture, the cardiovascular regulatory system is subjected to gravitational stress as there is pooling of blood in the lower limb. This consequent shifting of blood volume from central to peripheral compartment stimulates the vasomotor and cardiac center for physiological compensatory response of autonomic nervous system with sympathetic excitation and parasympathetic withdrawal to maintain the hemodynamics. $\frac{17,4}{4}$ Therefore, the integrity of autonomic response is crucial to maintain the normal blood flow when a subject is exposed to the gravitational effect due to change of posture as in the passive tilt test. Several sociodemographic and anthropometric factors are intrinsic to the variation of this hemodynamic response to the stress of postural challenge.10,18

There are various explanation about the effect of aging process on the cardiovascular regulation in health. It is well-recognized that the aging is accompanied by the progressive cardiac and vascular structural and functional changes. $19-21$

Research evidence from older people indicates that large arteries dilate and stiffen due to the thickening of the intima due to increase collagen content associated with reduced elastin content and vascular 
smooth muscle. These changes also reduce the responsiveness of afferent or efferent neural pathways and baroreceptor sensitivity. All these changes in advanced age may cause impairment of the ability for appropriate autonomic response in acute posture change. $\underline{19,20}$

Several studies observed reduced sympathetic and parasympathetic nervous system activity in older age. 22,23 In older age $\beta$-adrenergic activity and receptor sensitivity on the heart and blood vessels are reduced causing sympathetic impairment. Reduced baroreceptor sensitivity, loss of vagal tone and vagal damage is responsible for parasympathetic impairment. $\underline{22,23}$

In this study, uncompensated both heart rate and blood pressure response in the older females and only blood pressure response in older males may be attributed to the age-related changes in blood vessels as well as age-related impairment in neural regulation of cardiovascular system when subjected to postural stress during tilting.

The evidence from this study suggests the sympathetic attenuation in older males and both sympathetic and parasympathetic attenuation in older females when subjected to orthostatic stress. Lack of age effect on tissue perfusion based on the measurement of oxygen saturation is also noteworthy.

In addition, blood pressure response to tilting in this study, proposed attenuated cardiovascular response to orthostatic stress in females and males are similar.

In this study, comparatively greater fall of systolic blood pressure, observed in females than males strongly suggest less sympathetic response in females than males and the changes of baroreflex function may be different in males and females. $\underline{14,15}$

\section{Conclusion}

In response to tilting, a significant greater fall of systolic blood pressure, a smaller rise of diastolic blood pressure and mean arterial pressure were associated with advanced age in males. There were a significantly greater fall of systolic blood pressure, a smaller rise of diastolic blood pressure and heart rate were observed in females associated with advanced age in response to tilt.

\section{Ethical Issue}

The ethical clearance was obtained from the Institutional Review Board of the University. Approval paper was given by $182^{\text {th }}$ Institutional Review Board, Bangabandhu Sheikh Mujib Medical University, meeting held on 25th May 2019 (No. BSMMU/2019/6490).

\section{Conflict of Interest}

Authors declare no conflict of interest.

\section{References}

1. Sandhu KS, Khan P, Panting J, Nadar S. Tilt-table test: its role in modern practice. Clin Med. 2013; 13: 227-32.

2. Almquist A, Goldenberg IF, Milstein S, Chen MY, Chen X, Hansen R, Gornick CC, Benditt DG. Provocation of bradycardia and hypotension by isoproterenol and upright posture in patients with unexplained syncope. N Engl J Med. 1989; 320: 34651.

3. Grubb BP, Kimmel S. Head-upright tilt table testing: A safe and easy way to assess neurocardiogenic syncope. Postgrad Med. 1998; 103: 133-40.

4. Lambert E, Lambert GW. Sympathetic dysfunction in vasovagal syncope and the postural orthostatic tachycardia syndrome. Front Physiol. 2014; 5: 280.

5. Ricci F, De Caterina R, Fedorowski A. Orthostatic hypotension: Epidemiology, prognosis, and treatment. J Am Coll Cardiol. 2015; 66: 848-60.

6. Joseph A, Wanono R, Flamant M, Vidal-Petiot E. Orthostatic hypotension: A review. Nephrol Ther. 2017; 13: S55-67.

7. Freeman $R$, Abuzinadah AR, Gibbons $C$, Jones $P$, Miglis MG, Sinn DI. Orthostatic hypotension: JACC state-of-the-art review. J Am Coll Cardiol. 2018; 72: 1294-309.

8. Puppala VK, Dickinson O, Benditt DG. Syncope: Classification and risk stratification. J Cardiol. 2014; 63: 171-77.

9. Freeman R. Assessment of cardiovascular autonomic function. Clin Neurophysiol. 2006; 117: 716-30.

10. Dambrink JH, Wieling W. Circulatory response to postural change in healthy male subjects in relation to age. Clin Sci. 1987; 72: 335-41.

11. Bergström B, Lilja BO, Rosberg K, Sundkvist G. Autonomic nerve function tests. Reference values in healthy subjects. Clinl Physiol. 1986; 6: 523-28.

12. Hainsworth R, Al-Shamma YM. Cardiovascular responses to upright tilting in healthy subjects. Clin Sci. 1988; 74: 17-22.

13. Petersen ME, Williams TR, Gordon C, Chamberlain-Webber R, Sutton R. The normal response to prolonged passive head up tilt testing. Heart 2000; 84: 509-14.

14. Schondorf R, Low PA. Gender related differences in the cardiovascular responses to upright tilt in normal subjects. Clin Auton Res. 1992; 2: 183-87.

15. Shoemaker JK, Hogeman CS, Khan M, Kimmerly DS, Sinoway LI. Gender affects sympathetic and hemodynamic response to postural stress. Am J 
Physiol Heart Circ Physiol. 2001; 281: H2028-35.

16. Singer I, Edmonds HL. Tissue oximetry for the diag -nosis of neurally mediated syncope. Pacing Clin Electrophysiol. 2000; 23: 2006-09.

17. Mukai S, Lipsitz LA. Orthostatic hypotension. Clin Geriatr Med. 2002; 18: 253-68.

18. Jarvis SS, Florian JP, Curren MJ, Pawelczyk JA. Sex differences in vasoconstrictor reserve during $70 \mathrm{deg}$ head-up tilt. Exp Physiol. 201; 95: 184-93.

19. Tahvanainen A, Leskinen M, Koskela J, Ilveskoski E, Nordhausen K, Oja H, Kähönen M, Kööbi T, Mus -tonen J, Pörsti I. Ageing and cardiovascular respon -ses to head-up tilt in healthy subjects. Atherosclerosis 2009; 207: 445-51.

20. Murrell CJ, Cotter JD, George K, Shave R, Wilson L,
Thomas K, Williams MJ, Ainslie PN. Cardiorespiratory and cerebrovascular responses to headup tilt I: Influence of age and training status. Exp Gerontol. 201; 46: 9-17.

21. Okada Y, Galbreath MM, Shibata S, Jarvis SS, VanGundy TB, Meier RL, Vongpatanasin W, Levine $\mathrm{BD}, \mathrm{Fu} \mathrm{Q}$. Relationship between sympathetic baroreflex sensitivity and arterial stiffness in elderly men and women. Hypertension 2012; 59: 98-104.

22. Hogikyan RV, Supiano MA. Arterial alphaadrenergic responsiveness is decreased and SNS activity is increased in older humans. Am J Physiol Endocrinol Metab. 1994; 266: E717-24.

23. Islam T, Begum N, Ferdousi S. Autonomic neuropathy in healthy elderly person. J Bangladesh Soc Physiol. 2013; 8: 77-83. 